\title{
MATHEdunesa
}

Jurnal IImiah Pendidikan Matematika Volume 9 No. 1 Tahun 2020

ISSN :2301-9085

\section{PROSES BERPIKIR KOMPUTASI SISWA SMP DALAM MEMECAHKAN MASALAH POLA BILANGAN DITINJAU DARI PERBEDAAN JENIS KELAMIN}

\author{
Lintang Sekar Danindra \\ Pendidikan Matematika, Fakultas Matematika dan Ilmu Pengetahuan Alam, Universitas Negeri Surabaya \\ e-mail: lintangdanindra16030174011@mhs.unesa.ac.id

\section{Masriyah} \\ Pendidikan Matematika, Fakultas Matematika dan Ilmu Pengetahuan Alam, Universitas Negeri Surabaya \\ e-mail: masriyah@unesa.ac.id
}

\begin{abstract}
Abstrak
Salah satu keterampilan berpikir yang dibutuhkan pada abad 21 yaitu keterampilan berpikir komputasi. Salah satu faktor yang mempengaruhi proses berpikir komputasi siswa ialah jenis kelamin. Penelitian ini merupakan penelitian deskriptif dengan pendekatan kualitatif yang bertujuan untuk mendeskripsikan proses berpikir komputasi siswa SMP dalam memecahkan masalah pola bilangan ditinjau dari perbedaan jenis kelamin. Penelitian ini dilaksanakan di kelas VIII-G SMPN 13 Surabaya. Subjek dalam penelitian ini ialah satu siswa berjenis kelamin laki-laki dan satu siswa berjenis kelamin perempuan. Hasil dari penelitian ini adalah proses berpikir komputasi siswa laki-laki dan perempuan berkemampuan matematika tinggi melalui tahap dekomposisi, pengenalan pola, berpikir algoritma serta generalisasi pola dan abstraksi. Siswa laki-laki dalam proses dekomposisi memilih membaca berulang-ulang soal pemecahan masalah. Dalam proses pengenalan pola, dia membuat baris dan kolom untuk mengenali pola penyelesaian lalu memeriksa pola penyelesaiannya kembali. Dalam proses berpikir algoritma, dia menyebutkan langkah-langkah logis yang sesuai dengan pola penyelesaian yang telah dikenali. Dalam proses generalisasi pola dan abstraksi, dia menuliskan pola umum dan kesimpulan jawaban dari soal pemecahan masalah serta sangat yakin dengan jawaban yang diperoleh. Siswa perempuan dalam proses dekomposisi, dia membaca sambil menggarisbawahi informasi penting pada soal pemecahan masalah. Dalam proses pengenalan pola, dia memisahkan setiap informasi penting yang ada dan menyatukan setiap informasi dengan karakteristik yang sama untuk mengenali pola penyelesaian dan melakukan pengecekan kembali. Dalam proses berpikir algoritma, dia menyebutkan langkah-langkah logis yang sesuai dengan pola penyelesaian yang telah dikenali. Dalam proses generalisasi pola dan abstraksi, dia menuliskan pola umum dan kesimpulan jawaban dari soal pemecahan masalah.
\end{abstract}

Kata kunci: Berpikir Komputasi, Pola Bilangan, Jenis Kelamin.

\section{Abstract}

One of the thinking skills needed in the 21 st century is computational thinking skills. One of the factors that influence the computational thinking prosess is gender. This research is a descriptive research with a qualitative approach aimed to describe the computational thinking process of junior high school students in solving the problem of number patterns in terms of gender differences. This research was conducted in class VIII-G of SMPN 13 Surabaya.The subjects in this research were one male student and one female student. The results of this study are the process of thinking about the comparison of male and female student with high mathematical abilities through the installation of decomposition, introduction to patterns, algorithmic thinking and generalization of patterns and abstractions. Male student in the decomposition process chose to read over and over the problem solving problem. In the process of pattern recognition, he created rows and columns to recognize completion patterns and check again. In the process of thinking algorithms, he mentioned logical steps that are in accordance with the identified settlement patterns. In the process of generalizing patterns and abstractions, he written general patterns and conclusions answers to problem solving problems and is very sure of the answers obtained. Female student in the decomposition process, she read while underlining important information on problem solving problems. In the process of pattern recognition, she separated every important information that exists and unifies every information with the same characteristics to recognize the pattern of completion and re-check. In the process of thinking algorithms, she mentioned logical steps that are in accordance with the identified settlement patterns. In the process of generalizing patterns and abstractions, she written general patterns and conclusions answers to problem solving.

Keywords : Computational Thinking, Number Patterns, Gender. 


\section{PENDAHULUAN}

Tantangan yang terjadi pada dunia pendidikan khususnya pada kurikulum sekolah yang semakin dinamis membuat Indonesia harus lebih peka dalam membuat kerangka pendidikan yang strategis, guna menjawab kompetisi global di abad 21 ini yang penuh dengan perkembangan ilmu teknologi dan informasi. Pada abad 21, ilmu pengetahuan dan ilmu teknologi yang berkembang begitu cepat, oleh karena itu para siswa dituntut agar dapat menguasai berbagai keterampilan supaya dapat bersaing secara global. NSTA (National Science Teacher Association) (2011) menyebutkan bahwa dalam proses pembelajaran, keterampilan yang harus dikembangkan pada abad 21 adalah keterampilan berpikir dan keterampilan pemecahan masalah. Hal tersebut selaras dengan tujuan pembelajaran matematika yang terdapat pada National Council of Teacher Mathematics/NCTM (dalam Rock and Brumbaugh, 2013) bahwa pada pembelajaran matematika dapat mengembangkan kemampuan: (1) pemecahan masalah (problem solving); (2) penalaran dan pembuktian (reasoning and prof); (3) komunikasi (communication); (4) koneksi (connection); (5) representasi (representation). Dari uraian di atas menunjukkan bahwa keterampilan berpikir dan keterampilan untuk memecahkan masalah merupakan faktor penting dalam pembelajaran matematika di sekolah khususnya pada abad 21 ini.

Hudojo (2005) menyatakan bahwa seseorang dikatakan berpikir apabila dia melakukan kegiatan mental. Kegiatan mental yang dimaksud ialah proses berpikir yang terjadi dalam otak. Soedjadi (2000) menyatakan bahwa objek dasar matematika yang berupa fakta, konsep, relasi/operasi dan prinsip merupakan hal-hal yang abstrak sehingga untuk memahaminya tidak cukup hanya dengan menghafal tetapi dibutuhkan adanya proses berpikir. Sedangkan menurut Isroil, dkk (2017) berpikir adalah aktivitas mental yang terjadi dalam pikiran untuk memproses informasi yang diterima dan dapat diamati pada perilaku yang nampak. Dengan demikian, dalam pembelajaran matematika diperlukan adanya penekanan pada proses berpikir siswa, salah satu tujuannya agar siswa terbiasa untuk mengolah dan mentransformasi informasi untuk memecahkan suatu masalah matematika.

Wing (2011) menyatakan bahwa berpikir komputasi akan menjadi keterampilan dasar yang digunakan oleh semua orang di dunia pada pertengahan abad 21. Pendapat tersebut selaras dengan Riley \& Hunt (dalam Khine, 2018) pada buku yang berjudul Computational Thinking In The STEAM Disciplines yang menyatakan bahwa memiliki keterampilan berpikir komputasi dapat meningkatkan keterampilan memecahkan masalah dan merupakan atribut kunci untuk berhasil di abad 21. Selain itu, Bailey \& Borwein (dalam Weintrop, 2015) menyatakan bahwa memperkenalkan praktik berpikir komputasi ke dalam kelas matematika merupakan hal yang penting karena nantinya para siswa akan terjun di dunia profesional. Menurut Ioannidou (2011), berpikir komputasi/computational thinking adalah serangkaian pola pemikiran yang mencakup: memahami soal pemecahan masalah dengan gambaran yang sesuai, bernalar pada beberapa tingkat abstraksi, dan mengembangkan penyelesaian otomatis. Rachim (2015) mendefinisikan bahwa berpikir komputasi sebagai keterampilan kognitif yang memungkinkan pendidik mendefinisikan pola, memecahkan masalah kompleks menjadi langkah-langkah kecil, mengatur dan membuat serangkaian langkah untuk memberikan solusi dan membangun representasi data melalui simulasi. Berpikir komputasi sebenarnya merupakan suatu pendekatan dalam proses pembelajaran yang mempunyai peranan penting dalam pengembangan sebuah aplikasi komputer, namun sebenarnya berpikir komputasi juga dapat digunakan untuk mendukung pemecahan masalah pada pembelajaran matematika. Seperti kata Denning \& Tedre (2019) dalam bukunya yang berjudul Computational Thinking yaitu "computational thinking is sometimes portrayed as a universal approach to problem solving", hal ini menunjukkan bahwa berpikir komputasi juga bisa dijadikan sebuah pendekatan untuk memecahkan suatu masalah. Berdasarkan penjabaran di atas, maka penelitian ini menggunakan indikator pemecahan masalah yang sesuai dengan keterampilan berpikir komputasi menurut Ioannidou (2011) yang akan disediakan pada tabel di bawah ini.

Tabel 1.Indikator Berpikir Komputasi

\begin{tabular}{|c|l|}
\hline $\begin{array}{c}\text { Keterampilan } \\
\text { Berpikir } \\
\text { Komputasi }\end{array}$ & \multicolumn{1}{|c|}{ Indikator } \\
\hline & $\begin{array}{l}\text { Mengidentifikasi informasi yang } \\
\text { diketahui dari soal pemecahan } \\
\text { masalah yang disajikan. }\end{array}$ \\
\cline { 2 - 3 } Dekomposisi & $\begin{array}{l}\text { Mengidentifikasi informasi yang } \\
\text { ditanyakan dari soal pemecahan } \\
\text { masalah yang disajikan. }\end{array}$ \\
\hline Pengenalan & $\begin{array}{l}\text { Mengenali pola atau karakteristik } \\
\text { yang sama/berbeda dalam } \\
\text { memecahkan soal pemecahan } \\
\text { masalah yang disajikan guna } \\
\text { membangun suatu penyelesaian. }\end{array}$ \\
\hline Berpikir & $\begin{array}{l}\text { Menyebutkan langkah-langkah logis } \\
\text { yang digunakan untuk menyusun } \\
\text { Algoritma }\end{array}$ \\
$\begin{array}{l}\text { suatu penyelesaian dari soal } \\
\text { pemecahan masalah yang disajikan. }\end{array}$ \\
\hline
\end{tabular}




\begin{tabular}{|c|c|}
\hline $\begin{array}{c}\text { Keterampilan } \\
\text { Berpikir } \\
\text { Komputasi }\end{array}$ & Indikator \\
\hline \multirow{2}{*}{$\begin{array}{l}\text { Generalisasi } \\
\text { Pola dan } \\
\text { Abstraksi }\end{array}$} & $\begin{array}{l}\text { Menyebutkan pola umum dari } \\
\text { persamaan/perbedaan yang } \\
\text { ditemukan dalam soal pemecahan } \\
\text { masalah yang disajikan. }\end{array}$ \\
\hline & $\begin{array}{l}\text { Menarik kesimpulan dari pola } \\
\text { yang ditemukan dalam soal } \\
\text { pemecahan masalah }\end{array}$ \\
\hline
\end{tabular}

Sehubungan dengan pelajaran matematika di sekolah, pola bilangan merupakan salah satu materi yang diajarkan kepada siswa SMP. Berdasarkan kurikulum 2013, salah satu aspek yang dipelajari dalam materi pola bilangan yaitu memecahkan masalah yang berkaitan dengan pola bilangan. Selain itu, pola bilangan juga dapat digunakan untuk mengasah keterampilan berpikir siswa. Anno (dalam Marion dkk, 2015) menyatakan bahwa pembelajaran pada materi pola bilangan dapat mengeksplorasi kemampuan berpikir yang dimiliki siswa. Marion (2015) berpendapat bahwa pembelajaran pada materi pola bilangan sangat penting, karena merupakan aktivitas matematika yang dapat mengembangkan kemampuan berpikir siswa. Selain itu, materi pola bilangan juga dapat dimodifikasi menjadi tipe soal pemecahan masalah matematika, sehingga dalam penggunaannya diharapkan dapat melihat proses berpikir komputasi siswa SMP.

Salah satu faktor yang tak kalah penting saat pembelajaran di kelas ialah faktor jenis kelamin siswa. Siswa laki-laki dan perempuan tentu memiliki perbedaan kognitif dan mempengaruhi kemampuan siswa saat belajar, sehingga siswa laki-laki dan perempuan tentu memiliki banyak perbedaan dalam memecahkan suatu masalah matematika. Arends (2008) menjelaskan bahwa terdapat perbedaan kognitif antara laki-laki dan perempuan, termasuk dalam memecahkan soal pemecahan masalah matematika. Dari perbedaan cara berpikir tersebut, tentu akan mempengaruhi proses berpikir komputasi siswa laki-laki dan perempuan dalam memecahkan masalah pola bilangan.

Salah satu penelitian sebelumnya yang dianggap relevan dengan penelitian ini yaitu penelitian yang dilakukan oleh Mufida (2018) yang berjudul "Profil Berpikir Komputasi dalam Menyelesaikan Bebras Task Ditinjau dari Kecerdasan logis Matematika Siswa".
Perbedaan penelitian ini dengan Mufida (2018) ialah jenis soal pemecahan yang digunakan masalah dan tinjauan dalam penelitian. Jenis soal pemecahan masalah pada penelitian Mufida (2018) menggunakan masalah bebras task, sedangkan pada penelitian ini menggunakan soal pemecahan masalah materi pola bilangan. Penelitian Mufida (2018) ditinjau dari kecerdasan logis matematika siswa, sedangkan pada penelitian ini ditinjau dari perbedaan jenin kelamin

Berdasarkan uraian di atas, peneliti ingin meneliti bagaimana proses berpikir komputasi siswa SMP dalam memecahkan masalah pola bilangan ditinjau dari perbedaan jenis kelamin.

\section{METODE}

Jenis penelitian ini termasuk penelitian deskriptif dengan pendekatan kualitatif. Penelitian ini dirancang untuk memahami dan menggambarkan suatu fenomena yang dialami dengan cara mendeskripsikan dalam bentuk kata-kata dan bahasa. Data yang dideskripsikan ialah data kualitatif tentang proses berpikir komputasi siswa SMP dalam memecahkan masalah pola bilangan ditinjau dari perbedaan jenis kelamin. Instrumen yang digunakan dalam penelitian ini yaitu lembar Tes Kemampuan Matematika (TKM), lembar Tes Pemecahan Masalah (TPM) matematika, dan pedoman wawancara yang telah di konsultasikan dengan dosen pembimbing dan guru mata pelajaran matematika di SMPN 13 Surabaya, dan telah disetujui. Tes kemampuan matematika diberikan kepada 35 siswa di kelas VIII-G dengan diberikan waktu pengerjaan selama 30 menit. Setelah itu, hasil tes kemampuan matematika dikategorikan menjadi kategori kemampuan matematika tinggi, sedang, rendah. Kemudian dipilihlah dua siswa dengan kemampuan matematika tinggi yang setara, satu siswa berjenis kelamin laki-laki dan satu siswa berjenis kelamin perempuan. Kedua siswa kemudian diberi lembar tes pemecahan masalah dengan diberikan waktu pengerjaan selama 60 menit, kemudian dilakukan wawancara untuk memperoleh informasi yang lebih mendalam mengenai proses berpikir komputasi siswa SMP dalam memecahkan masalah pola bilangan. Wawancara yang digunakan yaitu semistructure interview yang pelaksanaannya lebih bebas dari wawancara terstruktur. Secara sistematis rancangan penelitian yang dilakukan dapat dilihat pada Bagan 1 . 


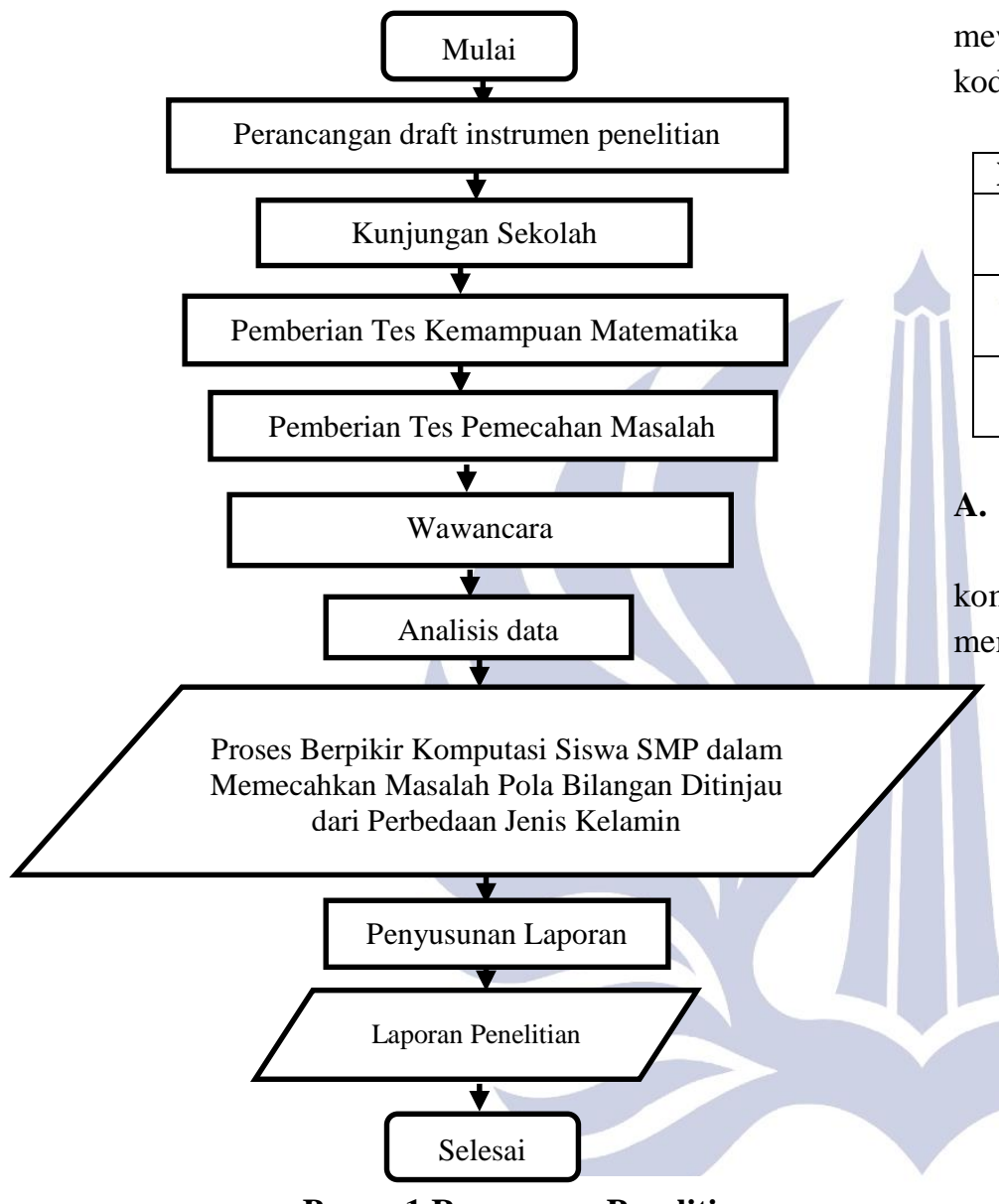

Bagan 1 Rancangan Penelitian

HASIL

PEMBAHASAN

Berikut disajikan hasil tes kemampuan matematika dari 35 siswa.

Tabel 2 Hasil Tes Kemampuan Matematika

\begin{tabular}{|c|c|c|c|}
\hline \multirow{2}{*}{$\begin{array}{c}\text { Kategori } \\
\text { Kemampuan } \\
\text { Matematika }\end{array}$} & \multirow[b]{2}{*}{ Skor Tes } & \multicolumn{2}{|c|}{ Jumlah Siswa } \\
\hline & & $\begin{array}{c}\text { Laki- } \\
\text { laki }\end{array}$ & $\begin{array}{c}\text { Perem } \\
\text { puan }\end{array}$ \\
\hline Tinggi & $80 \leq x \leq 100$ & 1 & 5 \\
\hline Sedang & $60 \leq x<80$ & 5 & 15 \\
\hline Rendah & $0 \leq x<60$ & 7 & 4 \\
\hline
\end{tabular}

Keterangan $x$ adalah nilai tes kemampuan matematika.

Dari ketegori kemampuan matematika di atas, kemudian dipilih dua siswa dengan kemampuan matematika tinggi, satu siswa berjenis kelamin laki-laki dan satu siswa berjenis kelamin perempuan, dan dikonsultasikan kepada guru mata pelajaran perihal kemampuan komunikasi siswa. Berikut rincian subjek penelitian yang terpilih pada penelitian ini.

Tabel 3 Subjek Penelitian

\begin{tabular}{|c|c|c|c|c|}
\hline No. & $\begin{array}{c}\text { Inisial } \\
\text { Siswa }\end{array}$ & Skor & $\begin{array}{c}\text { Jenis } \\
\text { Kelamin }\end{array}$ & $\begin{array}{c}\text { Kemampuan } \\
\text { Matematika }\end{array}$ \\
\hline 1 & RVR & 95 & L & Tinggi \\
\hline 2 & LLPD & 92 & P & Tinggi \\
\hline \multicolumn{5}{c}{ Untuk mempermudah penyajian transkrip }
\end{tabular}

wawancara, digunakan beberapa kode yang dapat mewakili peneliti dan subjek-subjek yang terpilih. Kodekode tersebut disajikan dalam tabel berikut.

Tabel 4 Transkrip Wawancara

\begin{tabular}{|c|c|l|}
\hline No. & Kode & \multicolumn{1}{|c|}{ Keterangan } \\
\hline 1. & Pn-00i & $\begin{array}{l}\text { Pertanyaan ke-i peneliti kepada } \\
\text { subjek penelitian. }\end{array}$ \\
\hline 2. & SLt-00i & $\begin{array}{l}\text { Jawaban ke-i subjek laki-laki } \\
\text { terhadap pertanyaan peneliti. }\end{array}$ \\
\hline 3. & SPt-00i & $\begin{array}{l}\text { Jawaban ke-i subjek perempuan } \\
\text { terhadap pertanyaan peneliti. }\end{array}$ \\
\hline
\end{tabular}

\section{A. Hasil Penelitian}

Berikut hasil analisis data proses berpikir komputasi siswa SMP laki-laki dan perempuan dalam memecahkan masalah pola bilangan.

Danin Bakery sedang menawarkan beberapa paket kue menarik khusus di hari ini, karena hari ini adalah hari ulang tahun Danin Bakery yang ke-7. Pada hari ulang tahunnya yang ke-7 ini, Danin Bakery menyediakan penawaran 7 paket kue yang menarik. Paket kue yang ditawarkan yaitu, paket $\mathrm{A}$ terdiri dari satu kue dengan satu ceri, paket $B$ terdiri dari dua kue dengan dua ceri untuk setiap kuenya, paket $\mathrm{C}$ terdiri dari tiga kue dengan tiga ceri untuk setiap kuenya, dan seterusnya. Tidak hanya itu, Danin Bakery juga memberikan bonus kue untuk pembelian mulai dari paket B. Setiap pembelian paket $\mathrm{B}$, maka mendapat tambahan bonus satu kue dengan satu ceri. Pembelian paket $C$, tambahan bonus yang diberikan yaitu satu kue dengan dua ceri. Pembelian paket $\mathrm{D}$, tambahan bonus yang diberikan yaitu satu kue dengan tiga ceri, dan seterusnya. Pada saat itu, Arya ingin membeli paket kue E, berapakah ceri yang didapatkan oleh Arya untuk pembelian paket kuenya?. Bagaimana cara anda mendapatkan jawaban tersebut? Jelaskan secara terperinci!

Gambar 1 Soal Tes Pemecahan Masalah

1. Proses berpikir komputasi siswa SMP laki-laki berkemampuan matematika tinggi dalam memecahkan masalah pola bilangan

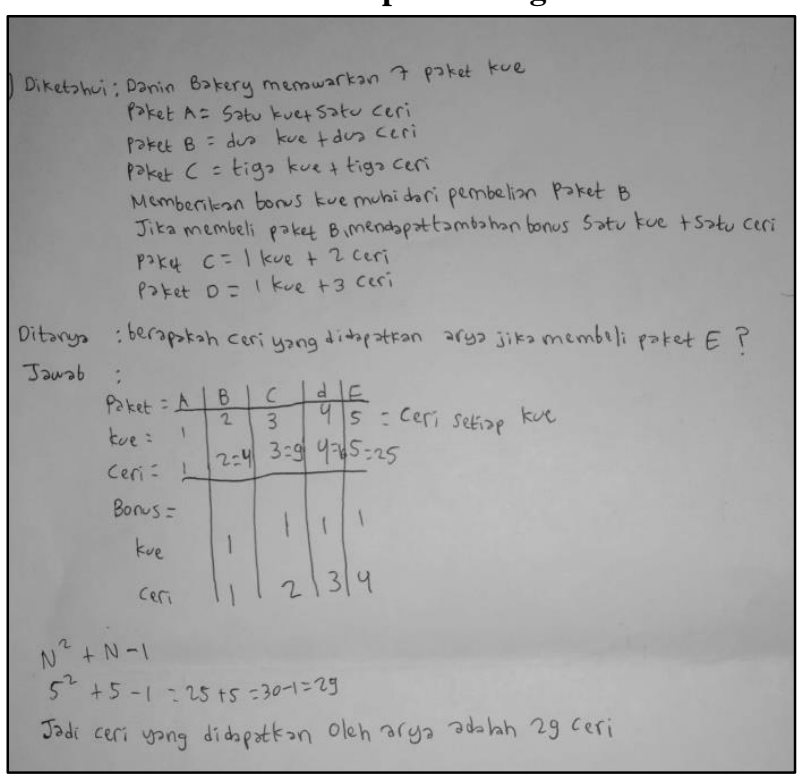

Gambar 2 Hasil Jawaban Siswa Laki-laki 
Berdasarkan uraian jawaban siswa berjenis kelamin lakilaki tersebut, peneliti melakukan wawancara untuk menggali informasi yang lebih mendalam mengenai proses berpkikir komputasi siswa dengan jenis kelamin laki-laki dalam memecahkan masalah pola bilangan.

\section{a. Proses pada Keterampilan Dekomposisi}

\section{Pn-001 Bagaimana kamu mengidentifikasi informasi dari soal pemecahan masalah tersebut?}

SLt-001 Saya baca berulang-ulang kak, kemudian saya tuliskan di lembar jawaban yang diketahui dan ditanyakan.

Berdasarkan hasil pekerjaan dan hasil wawancara yang telah dilakukan, terlihat bahwa dalam proses dekomposisi, siswa laki-laki memilih membaca berulangulang soal pemecahan masalah untuk mengidentifikasi informasi penting yang disajikan, barulah kemudian menuliskan informasi penting tersebut pada lembar jawaban.

\section{b. Proses pada Keterampilan Pengenalan Pola}

Pn-002 Apa yang kamu lakukan dalam mengerjakan soal pemecahan masalah tersebut?

SLt-002 Awalnya saya bingung kak, saya buat kolom-kolom dan barir-baris saja agar saya lebih mudah mengerjakannya

Pn-003 Bisa kamu jelaskan? (sambil menunjuk lembar jawaban)

SLt-003 Pertama kak, saya membuat kolom-kolom dan baris-baris untuk memisahkan paket, kue, ceri dan bonusnya, supaya saya tidak bingung kak. Lalu, saya tuliskan paket apa saja yang ada, kemudian saya tuliskan pada semua kolom untuk setiap paketnya dengan banyaknya kue, banyaknya ceri dan bonusnya kgak. Karena ini terkait dengan pola bilangan, maka saya misalkan setiap paket dengan pola bilangan. Paket A merupakan pola bilangan pertama, pada paket A mendapatkan satu kue dengan satu ceri. Paket B saya misalkan dengan pola bilangan ke-2, pada paket $\mathrm{B}$ mendapatkan dua kue dengan dua ceri setiap kue, maka paket B mendapatkan empat ceri. Karena terdapat tambahan bonus mulai dari pembelian paket $B$, untuk paket $B$ mendapat bonus satu kue dan satu ceri, maka pembelian paket B mendapatkan lima ceri. Paket $\mathrm{C}$ saya misalkan pola bilangan ke-3, pada paket $\mathrm{C}$ mendapatkan tiga kue dengan tiga ceri setiap kuenya, maka total ceri yang didapatkan ialah sembilan. Paket C mendapatkan tambahan bonus dua ceri, maka total ceri yang didapatkan pada paket $\mathrm{C}$ ialah sebelas ceri.

Pn-004 Coba kamu jelaskan kesimpulan bagaimana cara untuk mengetahui banyaknya ceri yang didapat untuk setiap pembelian paketnya!

SLt-004 Kesimpulannya, karena ini berkaitan dengan pola bilangan, maka saya misalkan setiap paket dengan variabel $n$, jadi $n$ merupakan pola bilangan k-1 sampai ke-7. Maka untuk mengetahui banyaknya ceri pada setiap paketnya yaitu $n$ saya pangkatkan dengan dua, lalu saya tambah $\mathrm{n}$ dan diminus satu.

Berdasarkan hasil pekerjaan dan hasil wawancara yang telah dilakukan, terlihat bahwa dalam proses pengenalan pola, siswa laki-laki awalnya mengalami kebingungan, sehingga akhirnya memutuskan untuk membuat kolom-kolom dan baris-baris yang kemudian diisi dengan paket-paket kue beserta jumlah ceri yang diperoleh pada setiap pembelian paket kue. Selanjutnya, memisalkan setiap paket dengan pola bilangan. Kemudian mengenali pola guna membangun pola penyelesaian dari soal pemecahan masalah, yaitu $\mathrm{n}$ dipangkatkan dengan dua, lalu ditambah $\mathrm{n}$ dan dikurang 1. Dan terakhir melakukan pengecekan terhadap pola penyelesaian yang telah dikenali.

\section{c. Proses pada Keterampilan Berpikir Algoritma}

Pn-005 Coba kamu sebutkan, bagaimana langkahlangkah kamu untuk mengetahui banyaknya ceri yang didapat oleh Arya untuk pembelian paket E!

SLt-005 Jadi begini kak, karena Arya membeli paket kue E maka pola bilangan yang terbentuk merupakan pola bilangan ke-5, kak.

Pn-006 Iya, selanjutya dek?

SLt-006 Selanjutnya kak, lima saya pangkatkan dengan dua, lalu saya tambah lima, setelah itu diminus satu, kak.

Berdasarkan hasil wawancara yang telah dilakukan, terlihat bahwa dalam proses berpikir algoritma siswa laki-laki menyebutkan langkah-langkah logis dalam menjawab soal pemecahan masalah yang disajikan dan sesuai dengan pola penyelesaian yang dikenali sebelumnya.

\section{d. Proses pada Keterampilan Generalisasi Pola dan} Abstraksi

Pn-006 Coba kamu sebutkan pola umum/rumus umum dari soal pemecahan masalah tersebut!

SLt-006 Rumus yang didapatkan dari soal pemecahan masalah tersebut ialah $\mathrm{N}^{2}+\mathrm{N}-$ 1 . 
Pn-007 Apakah penulisan variabel menggunakan huruf besar?

SLt-007 Emmm, salah ya kak? Seharusnya menggunakan huruf kecil kak. Hehe

Pn-008 Coba disebutkan dengan lengkap.

SLt-008 Jadi rumus umumnya ialah, $\mathrm{Un}=\mathrm{n}^{2}+\mathrm{n}-1$, dan $\mathrm{n}$ merupakan pola bilangan yang terbentuk.

Pn-009 Coba sebutkan apakah jawaban yang kamu peroleh dari soal pemecahan masalah tersebut?

$$
\begin{aligned}
\text { SLt-009 } \quad \mathrm{U}_{5} & =5^{2}+5-1 \\
& =25+4 \\
& =29
\end{aligned}
$$

Berdasarkan hasil pekerjaan dan hasil wawancara yang telah dilakukan, terlihat bahwa dalam proses generalisasi pola dan abstraksi siswa laki-laki menyebutkan rumus umum dari soal pemecahan masalah yang sesuai dengan pola yang telah dikenali sebelumnya, meskipun dalam penulisan rumus umum masih kurang tepat, tetapi telah dibenarkan saat proses wawancara berlangsung. Siswa laki-laki menarik kesimpulan berupa jawaban dari soal pemecahan masalah dengan menggunakan rumus umum yang ditemukan.

2. Proses berpikir komputasi siswa SMP perempuan berkemampuan matematika tinggi dalam memecahkan masalah pola bilangan

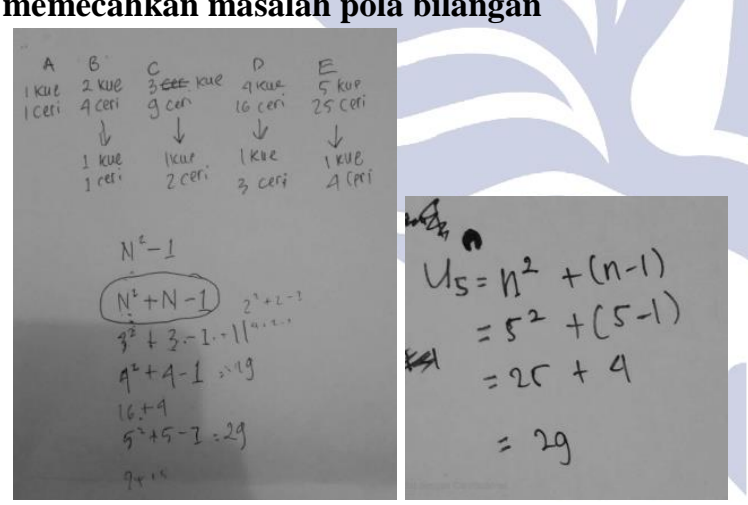

Gambar 3 Hasil Jawaban Siswa Perempuan

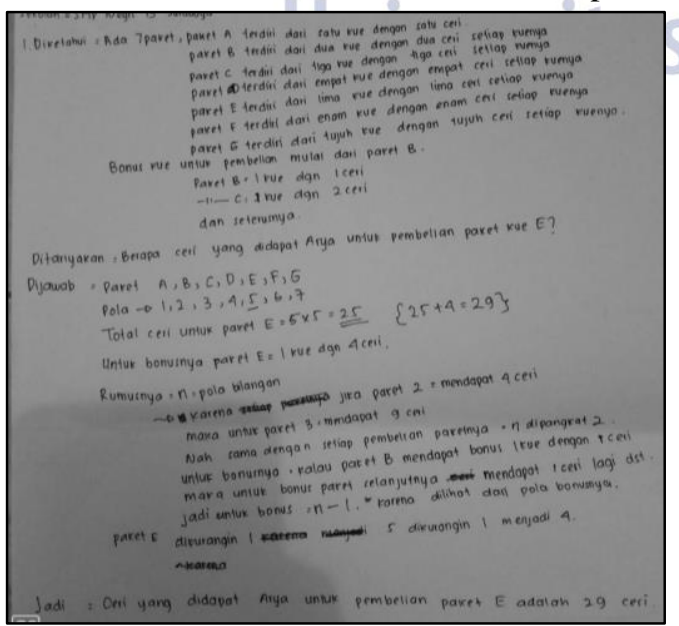

Gambar 4 Hasil Jawaban Siswa Perempuan
Berdasarkan uraian jawaban siswa berjenis kelamin perempuan tersebut, peneliti melakukan wawancara untuk menggali informasi yang lebih mendalam mengenai proses berpikir komputasi siswa dengan jenis kelamin perempuan dalam memecahkan masalah pola bilangan.

\section{a. Proses pada Keterampilan Dekomposisi}

\section{Pn-001 Bagaimana cara kamu dapat mengidentifikasi informasi yang ada pada soal pemecahan masalah?}

SPt-001 Saya baca kak soalnya sambil menggaris bawahi yang diketahui dan yang ditanyakan.

Berdasarkan hasil pekerjaan dan hasil wawancara yang telah dilakukan, terlihat bahwa dalam proses dekomposisi, siswa perempuan memilih membaca soal pemecahan masalah sambil menggaris bawahi informasi penting berupa informasi yang diketahui dan ditanyakan untuk mengidentifikasi informasi penting yang disajikan, barulah kemudian menuliskan informasi penting tersebut pada lembar jawaban.

\section{b. Proses pada Keterampilan Pengenalan Pola}

Pn-002 Apa yang kamu lakukan dalam mengerjakan soal pemecahan masalah tersebut?

SPt-002 Pertama kak, saya memisalkan setiap paketnya dengan pola bilangan, kemudian saya pisahkan setiap paket kue yang tersedia, lalu saya tuliskan jumlah kue dan jumlah ceri yang didapatkan untuk setiap pembelian paketnya, seperti ini kak (subjek menunjuk lembar jawaban).

$P n-003$ Coba kamu jelaskan apakah ada keterkaitan antara setiap paketnya dengan jumlah ceri yang diperoleh!

SPt-003 Jadi begini kak, pertama saya misalkan paket A, B, C, D sampai G menjadi pola kesatu, kedua, ketiga dan seterusnya kak. Maka, untuk pola kesatu mendapatkan satu ceri. Pola kedua mendapatkan empat ceri ditambah dengan bonus satu ceri. Paket ketiga mendapatkan sembilan ceri ditambah dengan bonus dua ceri, dan seterusnya kak. Pn-004 Apakah kamu bisa mengenali pola penyelesaiannya?

SPt-004 Jadi kak, awalnya untuk setiap paketnya saya ganti dengan $n$, lalu kemudian dipangkatkan dua, setelah itu ditambah $n$ lagi, lalu dikurangi satu.

Berdasarkan hasil pekerjaan dan hasil wawancara yang telah dilakukan, terlihat bahwa dalam proses pengenalan pola, siswa perempuan memisalkan setiap paket kue dengan pola bilangan, kemudian memisahkan setiap paket kue yang tersedia dan disatukan dengan banyaknya kue dan ceri yang diperoleh untuk setiap pembelian paket kue yang memiliki karakteristik sama. 
Kemudian mengenali pola guna membangun penyelesaian dari soal pemecahan masalah, yaitu dengan memisalkan setiap paket dengan $\mathrm{n}$ dan dipangkatkan dengan dua, lalu ditambah $\mathrm{n}$ dan dikurang 1. Dan terakhir melakukan pengecekan terhadap pola penyelesaian yang telah dikenali.

\section{c. Proses pada Keterampilan Berpikir Algoritma}

Pn-005 Coba kamu sebutkan, bagaimana langkahlangkah kamu untuk mengetahui banyaknya ceri yang didapat oleh Arya untuk pembelian paket E!

SLt-005 Jadi pertama, paket E dimisalkan pola ke-5, selanjutnya 5 dipangkatkan dua, setelah itu ditambah lima, lalu dikurangi satu kak.

Berdasarkan hasil wawancara yang telah dilakukan, terlihat bahwa dalam proses berpikir algoritma, siswa perempuan menyebutkan langkah-langkah logis dalam menjawab soal pemecahan masalah yang disajikan dan sesuai dengan pola penyelesaian yang dikenali sebalumnya.

d. Proses pada Keterampilan Generalisasi Pola dan Abstraksi

Pn-006 Coba kamu sebutkan pola umum/rumus umum dari soal pemecahan masalah tersebut!

SLt-006 Rumus yang didapatkan dari soal pemecahan masalah tersebut adalah $\mathrm{U}_{\mathrm{n}}=$ $\mathrm{n}^{2}+\mathrm{n}-1$.

Pn-007 Coba sebutkan apakah jawaban yang kamu peroleh dari soal pemecahan masalah tersebut?

SLt-007 Jadi, saya menggunakan rumus yang telah saya dapatkan tadi kak. Karena, rumus adalah $\mathrm{U}_{\mathrm{n}}=\mathrm{n}^{2}+\mathrm{n}-1$.

Jadi, $\mathrm{U}_{5}=5^{2}+5-1=25+4=29$. Jadi ceri yang diperoleh Arya dalam pembelian paket E sebanya 29 ceri.

Berdasarkan hasil pekerjaan dan hasil wawancara yang telah dilakukan, terlihat bahwa dalam proses generalisasi pola dan abstraksi, siswa perempuan menyebutkan rumus umum dari soal pemecahan masalah yang sesuai dengan pola yang telah dikenali sebelumnya, serta menarik kesimpulan berupa jawaban dari soal pemecahan masalah dengan menggunakan rumus umum yang ditemukan.

\section{B. Pembahasan}

Berdasarkan analisis data yang telah diuraikan di atas, maka pembahasan mengenai proses berpikir komputasi siswa SMP laki-laki dan perempuan dalam memecahkan masalah pola bilangan, sebagai berikut.

\section{Proses Berpikir Komputasi Siswa SMP Laki-laki dalam Memecahkan Masalah Pola Bilangan}

Pada proses dekomposisi, siswa laki-laki dalam mengidentifikasi informasi yang terdapat pada soal pemecahan masalah memilih untuk melakukan beberapa kali membaca soal pemecahan masalah supaya dapat mengidentifikasi informasi yang diketahui dan ditanyakan, kemudian menuliskan informasi yang diperoleh pada lembar jawaban. Dia juga menjelaskan apakah infomasi penting yang disajikan sudah cukup untuk menemukan jawaban dari soal pemecahan masalah yang disajikan. Dalam proses pengenalan pola, pertama yang dia lakukan yaitu membuat baris-baris dan kolomkolom untuk memisahkan setiap paket kue dan ceri yang terdapat dalam setiap paketnya, kemudian memisalkan setiap peket kue dengan pola bilangan, setetah itu mengenali karakteristik yang sama/berbeda guna membangun suatu penyelesaian, dan terakhir menyimpulkan bahwa pola penyelesaian dari soal pemecahan masalah yaitu untuk setiap paket dimisalkan dengan variabel $n$, maka penyelesaiannya dengan cara $n$ dipangkatkan dua lalu ditambah $\mathrm{n}$ dan dikurangi satu. Dia juga melakukan pengecekan dari pola penyelesaian yang telah dikenali. Setelah itu, dalam proses berpikir algoritma dia menyebutkan langkah-langkah logis yang digunakan untuk menyusun suatu penyelesaian dari soal pemecahan masalah yang disajikan dan sesuai dengan kesimpulan pola yang telah dikenali sebelumnya. Dalam proses generalisasi pola dan abstraksi, aktivitas yang pertama dia lakukan yaitu, mengaitkan dan menyimpulkan rumus umum pada soal pemecahan masalah dari proses pengenalan pola sebelumnya, sehingga dia menyebutkan bahwa rumus umum dari soal pemecahan masalah yaitu $\mathrm{Un}=\mathrm{n}^{2}+\mathrm{n}-1$. Tetapi dalam proses generalisasi pola, dia menuliskan variabel $\mathrm{n}$ menggunakan huruf besar, dan membenarkan kekurangannya saat proses wawancara dilakukan. Selanjutnya, proses dalam menarik kesimpulan dari pola umum yang ditemukan pada soal pemecahan masalah, dia menggunakan rumus umum yang telah ditemukan sehingga dia memberikan kesimpulan jawaban dari soal pemecahan masalah dengan jawaban yang benar, hal ini sesuai dengan pendapat Nurman (2008) bahwa siswa yang berkemampuan matematika tinggi lebih mampu memecahkan soal pemecahan masalah dengan benar.

Secara keseluruhan, siswa SMP laki-laki dalam proses memecahkan masalah pola bilangan menggunakan empat aspek pada keterampilan berpikir komputasi yang dimiliki, hal tersebut sesuai dengan pendapat Ioannidou (2011) yang menyatakan bahwa terdapat empat aspek keterampilan berpikir komputasi dalam memecahkan suatu masalah matematika. Hal tersebut juga sesuai dengan hasil penelitian yang dilakukan oleh Alfina (2017), yang menyatakan bahwa berpikir komputasi siswa lakilaki dalam memecahkan masalah matematika 
menggunakan semua aspek keterampilan berpikir komputasi. Meskipun ada tahap dimana siswa SMP lakilaki mengalami kesulitan dalam menyampaikan alasan pada proses memecahkan masalah pola bilangan yang disajikan, kemungkinan yang terjadi siswa SMP laki-laki kurang yakin dengan alternatif jawaban yang dibuatnya, sehingga ketika mengungkapkan proses berpikirnya perlu beberapa pertanyaan arahan untuk mendapatkan jawaban yang sesuai.

\section{Proses Berpikir Komputasi Siswa SMP Perempuan dalam Memecahkan Masalah Pola Bilangan}

Pada proses dekomposisi, siswa SMP perempuan dalam mengidentifikasi informasi yang diketahui dan ditanyakan dari soal pemecahan masalah memilih untuk membaca soal pemecahan masalah sambil menggaris bawahi informasi yang diketahui dan ditanya, kemudian menuliskan informasi tersebut pada lembar jawaban dengan bahasanya sendiri, hal ini sesuai dengan pendapat Arifin dan Bharata (2017) yang menyatakan bahwa siswa dengan jenis kelamin perempuan cenderung menuliskan apa yang dia mengerti. Dalam proses pengenalan pola, pertama dia memisalkan setiap paket dengan pola bilangan, kemudian memisahkan setiap paket kue dan menuliskan jumlah ceri yang didapatkan untuk setiap pembelian paket kue, setelah itu mengenali karakteristik yang sama/berbeda guna membangun suatu penyelesaian dari soal pemecahan masalah, selanjutnya menyimpulkan bahwa pola penyelesaian dari soal pemecahan masalah yaitu untuk setiap paketnya dimisalkan dengan variabel $n$, maka penyelesaiannya dengan cara $\mathrm{n}$ dipangkatkan dua lalu ditambahkan $n$ dan dikurangi satu, terakhir siswa SMP perempuan mengecek ulang apakah simpulan pola penyelesaian yang diperoleh berlaku untuk setiap paket kue yang tersedia. Selain itu, dalam proses berpikir algoritma dia menyebutkan langkah-langkah logis yang digunakan untuk menyusun suatu penyelesaian dari soal pemecahan masalah yang disajikan dan sesuai dengan kesimpulan pola yang telah dikenali sebelumnya. Dalam proses generalisasi pola dan abstraksi, pertama dia mengaitkan dan menyimpulkan rumus umum dari proses pengenalan pola sebelumnya, sehingga menyebutkan bahwa rumus umum dari soal pemecahan masalah, yaitu $\mathrm{Un}=\mathrm{n}^{2}+\mathrm{n}-1$. Selanjutnya, dia menarik kesimpulan dari pola umum yang ditemukan dalam soal pemecahan masalah yang disajikan menggunakan rumus umum yang telah didapat, sehingga dia memberikan kesimpulan jawaban dari soal pemecahan masalah yang disajikan dengan benar, hal ini sesuai dengan pendapat Nurman (2008) bahwa siswa yang berkemampuan matematika tinggi lebih mampu memecahkan soal pemecahan masalah dengan benar.
Secara keseluruhan, siswa SMP perempuan menyelesaikan masalah pola bilangan menggunakan empat aspek pada keterampilan berpikir komputasi yang dimiliki. Hal tersebut sesuai dengan pendapat Ioannidou (2011) bahwa terdapat empat aspek keterampilan berpikir komputasi dalam memecahkan suatu masalah matematika. Hal tersebujt juga sesuai dengan hasil penelitian yang dilakukan oleh Alfina (2017), yang menyatakan bahwa berpikir komputasi siswa perempuan dalam memecahkan masalah matematika menggunakan semua aspek keterampilan berpikir komputasi.

\section{PENUTUP}

\section{Simpulan}

1. Proses berpikir komputasi siswa SMP laki-laki dalam memecahkan masalah pola bilangan, sebagai berikut: (1) pada proses dekomposisi, siswa laki-laki memilih untuk membaca beberapa kali soal pemecahan masalah, barulah dapat mengidentifikasi informasi yang diketahui dan ditanyakan dari soal pemecahan masalah yang disajikan dan kemudian menuliskan informasi penting pada lembar jawaban. (2) pada proses pengenalan pola, siswa laki-laki membuat kolom-kolom dan baris-baris yang kemudian diisi dengan paket-paket kue beserta jumlah ceri yang diperoleh pada setiap pembelian paket kue. Selanjutnya, memisalkan setiap paket dengan pola bilangan. Barulah mengenali pola pada soal pemecahan masalah guna membangun suatu penyelesaian, dan terakhir melakukan pengecekan terhadap pola penyelesaian yang telah dikenali. (3) pada proses berpikir algoritma, siswa laki-laki menyebutkan langkah-langkah logis dalam menjawab soal pemecahan masalah yang disajikan dan sesuai dengan pola penyelesaian yang dikenali sebelumnya. (4) pada proses generalisasi pola dan abstraksi, siswa laki-laki menyebutkan rumus umum dari soal pemecahan masalah yang sesuai dengan pola yang telah dikenali sebelumnya, meskipun dalam penulisan rumus umum masih kurang tepat, tetapi telah dibenarkan saat proses wawancara berlangsung. Siswa laki-laki menarik kesimpulan berupa jawaban dari soal pemecahan masalah dengan menggunakan rumus umum yang ditemukan.

2. Proses berpikir komputasi siswa SMP perempuan dalam memecahkan masalah pola bilangan, sebagai berikut: (1) pada proses dekomposisi, siswa perempuan membaca soal pemecahan masalah sambil menggarisbawahi informasi penting yang diketahui dan ditanyakan dari soal pemecahan masalah, kemudian menuliskan informasi penting tersebut pada lembar jawaban. (2) pada proses pengenalan pola, siswa perempuan memisalkan setiap paket kue dengan 
pola bilangan, kemudian memisahkan setiap paket kue yang tersedia dan disatukan dengan banyaknya kue dan ceri yang diperoleh untuk setiap pembelian paket kue. Kemudian mengenali pola guna membangun penyelesaian dari soal pemecahan masalah, dan terakhir melakukan pengecekan terhadap pola penyelesaian yang telah dikenali. (3) pada proses berpikir algoritma, siswa perempuan menyebutkan langkah-langkah logis dalam menjawab soal pemecahan masalah yang disajikan dan sesuai dengan pola penyelesaian yang dikenali sebalumnya. (4) pada proses generalisasi pola dan abstraksi, siswa perempuan menyebutkan rumus umum dari soal pemecahan masalah yang sesuai dengan pola yang telah dikenali sebelumnya, serta menarik kesimpulan berupa jawaban dari soal pemecahan masalah dengan menggunakan rumus umum yang ditemukan.

\section{Saran}

Berdasarkan penelitian yang telah dilakukan, peneliti mengemukakan beberapa saran sebagai berikut.

1. Guru sebaiknya merancang pembelajaran yang sesuai dengan tahapan proses berpikir komputasi siswa, misalnya dengan memberikan soal menantang untuk melatih keterampilan berpikir komputasi siswa dalam memecahkan masalah matematika dengan memperhatikan faktor jenis kelamin para siswa.

2. Bagi peneliti lain, hendaknya memberikan pertanyaan yang lebih dalam pada saat melakukan wawancara supaya dapat menggali informasi lebih mendalam tentang proses berpikir komputasi siswa.

\section{DAFTAR PUSTAKA}

Alfina, Azza. 2017. Berpikir Komputasional Siswa dalam Menyelesaiakn Masalah yang Berkaitan dengan Aritmetika Sosial Ditinjau dari Gender. SimkiTechsain Vol. 01 No. 04 Tahun 2017.

Arends. 2008. Learning to Teach. Yogyakarta: Pustaka Belajar.

NSTA, C. S. (2011). Computational Thinnking Teacher Resource., Nasional Science Foundation Under Grant.

Denning, P., \& Matti, T. 2019. Computational Thinking. United State: Library of Congress Under Grant.
Hudojo, H. 2005. Pengembangan Kurikulum dan Pembelajaran Matematika. Malang: UM Press.

Ioannidou, A. (2011). Computational Thinking Patterns . Annual Meeting of the American Educational Research Association (AERA), 4.

Isroil, A., Budayasa, I.K., dan Masriyah. 2017. Profil Berpikir Siswa SMP dalam Menyelesaikan Masalah Pola Bilangan Ditinjau dari Kemampuan Matematika. JRPM, 2017, 2(2), 93 105

Marion, dkk. 2015. Desain Pembelajaran Pola Bilangan Menggunakan Model Jaring Laba-Laba Di SMP. Jurnal Kependidikan, Volume 45, Nomor 1, Mei 2015, Halaman 44-61

Nurman, Try Azizah. 2008. "Profil Kemampuan Siswa SMP Dalam Memecahkan Masalah Matematika OpenEnded Ditinjau dari Perbedaan Tingkat Kemampuan Matematika". Tesis tidak dipublikasikan. Surabaya: PPs Universitas Negeri Surabaya.

Rachim, F. Computational Thinking Computer Science, Kompasiana, diakses pada tanggal 25 Oktober $2019 . \quad$ (online) tersedia: https://www.kompasiana.com/fathur_rachim/55e 06cc71593736c0a109023/computationalthinking-computerscience?page $=$ all

Rock, D. \& Brumbaugh. 2013. Teaching Secondary Mathematics. New York: Routlegde Taylor and Francis Group.

Sholikhah, R.N dan Masriyah. 2019. Proses Berpikir Kreatif Siswa SMP dalam Memecahkan Masalah Matematika Ditinjau dari Tingkat Kemampuan Matematika dan Jenis Kelamin. Jurnal Ilmiah Pendidikan Matematika Volume 8 No. 2 Tahun 2019 ISSN :2301-9085

Soedjadi. 2000. Kiat Pendidikan Matematika di Indonesia. Jakarta: Direktorat Jendral Pendidikan Tinggi, Departemen Pendidikan Nasional.

Weintrop, D., \& dkk. (2015). Defining Computational Thinking for Mathematics and Science Classrooms. J Sci Educ Technol, DOI 10.1007/s10956-015-9581-5.

Wing, J. (2011). Computational thinking. New York City: Association for Computing Machinery 